\title{
The European system of financial supervision - regulatory impact assessment
}

\author{
Mariusz Szpringer \\ Warszaw School Of Economics \\ m.szpringer@gmail.com \\ Włodzimierz Szpringer ${ }^{1}$ \\ Warsaw School of Economics \\ wloszp@wp.pl
}

\begin{abstract}
Complexity and uncertainty in the application of the regulations of the European system of financial supervision are due to the fact that its particular elements were implemented over a period of time. First, it was a system of European financial supervision authorities i.e. the European Banking Authority (EBA), the European Insurance and the Occupational Pensions Authority (EIOPA) and the European Securities and Markets Authority (ESMA), whose main objective was to coordinate national actions. Then there were established the European Banking Union, including the Single Supervisory Mechanism (SSM), the Single Resolution Mechanism (SRM), as well as the European Stability Mechanism (ESM), which constitutes also a part of the system of support for endangered banks. Legal interpretation problems are a result of differences in the scope of competences of these entities. For example, there is uncertainty whether the regulations refer to the eurozone or the whole European Union and if they refer to banks only or to other financial institutions as well. An analysis of the SSM, the SRM or the ESM does not always offer a clear answer to questions such as: who, when and using what tools should act; when, for example, the ECB may and should correct the decisions of national supervisors; what is the role of the ESRB, if we take account of the enhanced competences of the ECB in the banking union; if and when banks may question supervisory decisions concerning, for example, establishing a buffer or classifying an institution as SIFI, etc. Similarly, the role of the EBA or the ESM is unclear in the context of the establishment of the banking union, the SSM, the SRM, the ESM and the delegation of power of the ECB and the European Commission to regulatory agencies (Meroni doctrine) or the practice of establishing regulatory agencies outside the bounds of the treaty (Pringle doctrine). Therefore the regulatory landscape in this context requires impact assessment.
\end{abstract}

\section{JEL Classification: G28, K23, L51, N24}

Keywords: European banking union, European Central Bank, Single Supervisory Mechanism, Single Resolution Mechanism, European Stability Mechanism, Meroni, doctrine, regulatory impact assessment.

Corresponding author: Collegium of Business Administration, SGH Warsaw School of Economics, al. Niepodległości 162, 02-554 Warszawa, Tel: +48225649245, E-mail: wloszp@wp.pl 


\section{INTRODUCTION}

The aim of this paper is to provide a critical overview of regulatory shortcomings within the framework of the European banking union. The article does not seek to create a new theoretical model of European supervision of the financial market, but to provide a critical analysis of its extremely complex legal status and - on this basis - to indicate the directions of interpretation of EU and national law (e.g. the division of powers between the ECB and national supervisors, the presumption of competence of national supervisors, the possibility of corrective and regulatory actions of ECB to all banks, not just those systemically important or those in the euro area, if it comes to the issue of financial stability throughout the EU). The article aims at presenting the existing normative solutions against the background of very complex system of structural links within the supervisory authorities (e.g. ECB and ESRB, ECB and national regulators). It also gives a general assessment of the expected economic effects of the existing regulatory solutions.

It should be stressed that the analysis of the European system of financial supervision, as well as the interplay of micro- and macroprudencial supervision has already been provided many times in the European economic and legal literature (e.g. Lo Schiavo 2013; Lo Schiavo 2014; Faia et al., 2015; Kämerer, 2016, Tröger T 2015, Schoenmaker D 2014, Gurlit E. 2015).

Also in the Polish literature there are many examples of research in this field (e.g. Fedorowicz, 2011; Fedorowicz, 2014; Jurkowska-Zeidler, 2008; Szczepańska, 2012; Koleśnik, 2013; Stanisławiszyn, 2014; Szpringer, 2015).

The regulations of the banking union have met with substantial criticism (Faia et al., 2015; Kämerer, 2016). There is a risk of excessive centralization of the ECB's competences, which may lead, on the one hand, to a decision paralysis, and, on the other, to the ECB's excessive power over the market and financial institutions and to the appearance of new challenges of the ECB's supervision over the sector and problems of the integrated supervision (supervision of banks, insurance undertakings and investment firms) in some EU Member States. Supervisory competences of the ECB have their shortcomings. This, for example, refers to filing for bankruptcy in the banking sector or the bank's powers of investigation, moreover, there are no clear regulations concerning the cooperation between the supervisory authorities of non-participating and third countries. This raises a question about the prospects of creating an effective ECB supervision and building a financial potential of institutions, both national and European ones, responsible for recovery and resolution and guaranteeing deposits so as not to affect too much the financial results of banks.

The ECB has never been responsible for prudential supervision. The level of generality of the division of competences between the ECB and national supervisory authorities may result in excessive duration of the decision making process. There is also a risk that the regulations will not be well adjusted to the situation in the local markets. Conferring on the ECB almost all the supervision over credit institutions based in the countries of the eurozone may raise doubts from the point of view of Article 127(6) TFEU.

Pursuant to Article 127(6) TFEU final supervisory decisions are taken by the ECB's Governing Council, which limits parliamentary control because heads of central banks are independent. Supervisory decisions have extreme consequences for taxpayers, shareholders and banks' employees, therefore, they should be subject to control by the European Parliament and national parliaments. Moreover, delegating the decision-making power to the Governing Council means it will be easier to outvote non-eurozone countries and, therefore, the SSM is less attractive for such countries. It is especially important for the countries highly integrated with the eurozone, e.g. Poland and Hungary, which will find themselves at a disadvantage in comparison with banks from the eurozone (Szpringer, 2013).

The new supervision system performs both micro- and macroprudential functions. This means multiplying of supervisory structures, generating costs and hampering the transparency, including 
clear delineation of competences and responsibilities. It is also a challenge to ensure proper supervision over banks from outside the eurozone. Implementing a proper macroprudential policy which takes into consideration economic and social interests of individual countries, especially the peripheral ones and those outside the system of the common currency, may prove difficult.

The ECB single supervision will not have proper instruments to supervise the whole banking sector. What is most important is to manage a crisis in financial institutions "too big to fail". Strict supervision of the ECB over such entities appears to be the best solution. The controversies around the banking union arose due to the fact that the draft law prepared by the European Commission soon proved to be imprecise or too far-reaching and infringing on, sometimes conflicting, interests of some member states or generating additional costs for them. There are opinions that the banking union may increase the systemic risk (Koleśnik, 2013)

\section{THE DELEGATION OF POWERS OF THE COMMISSION OR THE COUNCIL TO REGULATORY AGENCIES (MERONI, DOCTRINE)}

The problem of defining the extent of the regulatory powers of the Commission or the Council without starting a complex, lengthy and uncertain procedure of amending the treaty was considered by the Court of Justice of the European Union in the Meroni case. The Court ruled that the legislative power of the Commission and hence its discretionary power may refer to the development of technical standards which are not legally binding, which are not politically influenced and which are within the framework of the treaty and the characteristics of a given public entity operating on the basis of the treaty. Moreover, they should contribute to a goal clearly defined in the Treaty for example, to the European integration or harmonisation of the laws and regulations. It is admissible to establish a new entity or a regulatory agency to this end.

Currently it is considered that the Single Resolution Mechanism (SRM) complies with the criteria of the Meroni case judgment. A single set of SRM tools contributes to the European integration and does not breach the TFEU regulations concerning the approximation of laws, including Article 114. In this context, the question of discretionary powers of regulatory bodies is of great importance. The power of discretion is used by the Single Recovery Board (SRB) mainly during the preparation of resolution plans to be presented to the Commission. However, there are questions raised concerning the SRB's criteria when evaluating the solvency of an institution and recommending a recovery and resolution plan and obliging the shareholders and bondholders of a bank to contribute to the bail-in. Discretionary power in such a case is, to a great extent, an act of knowledge, which should be based on the achievements of the science of finance and economics and should not be used for case-based reasoning, which is often subject to political bargaining.

The scope of discretionary powers of regulatory agencies was a subject of the court judgment on short selling. The UK government lodged a challenge to the Regulation of the European Parliament and the Council of the European Union No 236/2012 of 14 March 2012 on short selling and certain aspects of credit default swaps, which grants the European Securities and Markets Authority (ESMA) a power to prohibit or control short selling of credit default swaps in exceptional circumstances. Article 28 of this Regulation grants the ESMA a power to pass binding acts. However, such a power can be exercised only when there is a threat to the orderly functioning and integrity of financial markets in the Union.

The UK government argued that this regulation stands in contradiction to Treaty and invoked the Meroni and the Romano judgments, which, it claimed, set a standard for the proper reasoning and interpretation of the law (Case 9/56 Meroni vs High Authority [1957\&1958]) Romano Case (Case 98/80 Giuseppe Romano vs Institut National d'Assurance Maladie-Invalidité [1981]), (Griller, http://www.eba.europa.eu/documents/10180/498024/Presentation+-+Stefan+Griller. 
pdf, Armstrong http://europeanlawblog.eu/?p=2176 Retrieved March 30, 2016). Especially, in the light of the Meroni judgment the delegation of powers to the regulatory agencies cannot be excessive and, therefore, should not disturb the balance of the institutional powers of the EU and the member states. Additionally, according to the Romano judgment, administrative regulatory agencies are not empowered to adopt legally binding decisions. The UK invoked also Articles 290 and 191 of TFEU, which delegate the power to adopt acts of general application which have the force of law to the Commission and not to lower-tier agencies.

The opinion of Advocate General confirmed that the ESMA enjoys inordinately broad discretionary powers and this cannot be treated as mere implementation of acts of general application or the Treaty itself. However, the Court of Justice of the European Union found that the range of the discretionary powers does not go beyond the bounds of the regulatory framework as the exercise of such powers is circumscribed by various conditions. It is, by no means, free decision-making administrative discretion but a constrained decision which is subject to court's supervision. Therefore, it is compliant with the Meroni doctrine. The Court ruled also that the ESMA does not adopt measures of general application and thus it is not at odds with the Romano doctrine.

Referring to the alleged incompatibility with Articles 290 TFEU and 291 TFEU, the Court ruled that while the articles do not contain expressis verbis any provision to the effect that powers may be delegated, a number of provisions in the Treaty, nonetheless, presuppose that such a possibility exists. What is more, it is not about political acts but very specific measures implemented to preserve financial stability. The ESMA's decisions laid down in its regulations, to a large extent, can be considered as acts of knowledge based on a technical expert opinion. According to the Court, Article 28 of Regulation No 236/2012 must be read in conjunction with the other regulatory actions and cannot be regarded as contravening Articles 290 TFEU and 291 TFEU.

The Meroni doctrine was also disputed in the context of discretionary powers conferred on a new authority, the Single Resolution Board (SRB) under the Single Resolution Mechanism (SRM). First of all, in the light of the regulations banks or group of banks can be directed to take measures to change their organizational structure, if this structure is an impediment to restructuring of a group of banks, which is to be efficient and based on trust. The SRB acts in agreement with a national regulator, however, it may eventually enforce structural changes. Additionally, Article 10 of Regulation on a Single Resolution Mechanism requires taking into account the principle of proportionality when removing threats.

Both the SRB and the national regulator should in advance issue a notification informing the interested financial institution about the discovered threats so that the recovery and resolution plan could be implemented efficiently. Thus the institution has a chance to implement on its own the recovery measures it considers appropriate. It is within the discretion of the SRB to decide whether it will apply informative and warning measures instead of binding ones, whether it will use financial tools, or whether it will conduct structural intervention, which is the most farreaching form of intervention.

It is natural that structural measures in market economy always raise doubts as in the case of an antitrust instrument of splitting up a company or restructuring it after a merger. However, such tools are at the disposal of these institutions. The SRM gives rise to a debate on the SRB's right to decide on the contribution of the owners and even the bondholders to a bank's recapitalisation, so called bail-in. With this respect the SRB enjoys a discretionary power of deciding how to share the costs of rescuing a bank and if and to what extent use the SRF's public resources when, for example, a bank has completely lost access to private market. There are opinions that the SRB's wide discretionary powers may reduce trust of other market participants which might enter into contract with a bank at risk. 
Research is being conducted to find out to what extent the Single Supervisory Mechanism (SSM) adds to the institutional value when it comes to financial stability. To this end, the location of responsibility is being considered, which, effectively, means transferring it to the EU level, integrating the EU financial market and centralizing the supervision executed in cooperation with national supervision (top-down approach). The centralization of supervision is seen as an institutional addition to the banking union and the common currency, the euro.

Article 127(6) TFEU and the Statute of the ECB serve as a legal framework for vesting the ECB with the supervisory power, and hence, for centralizing financial supervision at the EU level. Despite continuous discussion on the scope of that power, as some writers see it as broad and blanket and others are very strict in interpreting its limitations, it is the only solid foundation of centralization. Other regulations of the Treaty, such as the so-called flexibility clause of Article 352 TFEU or Article 114 TFEU are considered to be insufficient. Article 127(5) of implied powers doctrine may serve as a partial basis for the centralization of supervision, however, it cannot be considered the only and sufficient one. As it has already been mentioned the court judgments in the Meroni and the Romano cases may offer some guidelines as to the interpretation of the scope of the power.

An analysis of the relations between the ECB and the European Banking Authority (EBA) leads to very interesting conclusions. In fact the Single Supervisory Mechanism has a supervisory function rather than a regulatory one, hence the ECB's actions should not interfere with the prerogatives of the EBA when it comes to the creation of technical standards or guidelines for the cohesion of banking supervision. However, Article 132 TFEU, which grants the ECB the power to make regulations, may raise concerns that the ECB may undermine the competences of the EBA. The regulations made by the ECB pursuant to Article $132 \mathrm{TFEU}$, by no means, are limited to the supervisory mandate of the ECB.

There are two options to strengthen the Single Supervisory Mechanism: the expansion of the supervisory role of the ECB or the enhancement of the functions of the EBA. In this case the EBA's role under Article 114 TFEU should not be limited to actions of last resort but should be treated as an organ of constant supervision with extensive instruments, including the power to take preventive measures. Article 114 entitles the EU to establish agencies, whose aim is to enforce the EU law. This competency was confirmed by the judgments of the Court of Justice of the European Union (ENISA) (Case C-217/04, United Kingdom/Parliament and Council (ENISA), ECR 2006, I-3771). After the crisis of 2010, by means of regulations, three new authorities were established: the European Banking Authority (the EBA), the European Insurance and Occupational Pensions Authority (EIOPA) and the European Securities and Markets Authority (ESMA), which together create a system of financial market supervision. A variety of different agencies and organizations have been established outside the bounds of the Treaty. Only some were Treaty-based (Europol). (Görisch, 2016)

In the light of the doctrine, delegation of power to such an agency created outside the bounds of the Treaty should not get out of control, competences should be clearly defined in the law establishing this institution. Political responsibility cannot be transferred to such a body and measures of legal protection should be specified. In the light of Article 291 TFEU such agencies are a product of so called comitology, which facilitates and speeds up the regulation of technical issues within the law of the EU and the application of the EU law. At the European level the need for more flexibility in the regulation of technical details led to the launch of a new approach to the development of regulations, so called Lamfalussy Process. (Christensen, 2005; Jacobson, 2007; Moynihand, 2006) Control over the EBA is exercised in such a way that, for example, the EBA's regulations require a resolution of the European Commission upon the request of the EBA. If the EBA's actions affect all member states, an approval of the European Parliament is required.

It has to be emphasized that, in the light of the law and Article 127(6) TFEU in particular, it is not possible to entrust the ECB with full supervision over all banks including those outside the 
eurozone and those outside the "specific tasks" of the ECB. Whatever solution will be adopted a question about the role of the EBA will persist. Certainly, expanding the tasks of the EBA would require tightening control by creating not only the Management Board with regulators from member states but also the Supervisory Board similar to German financial market supervisor (BaFin). (Repasi, 2012)

It is evident that the EBA as a regulatory agency is much constrained in its regulatory decisions which must be approved by the Commission. In the light of Regulation 1022/2013 the EBA Management Board in order to be able to perform regulatory, executive or mediation tasks needs a resolution of countries participating and not participating in the SSM taken by a qualified majority. In conclusion, we can say that the SSM and a new institutional position of the ECB will gradually limit the role of the EBA. There are concerns that even commitment to close cooperation may not eliminate conflicting situations, which will, in turn, not foster financial stability. The EBA will probably evolve from a typical supervisory institution to a bridge institution between the ECB and national authorities, especially these of non-eurozone countries. The role of the EBA in terms of technical standards, interpretation of the banking law and formulation of guidelines and recommendations fostering the harmonisation of legislation, so called Single Rulebook, remains unchanged. (Ferran, 2015)

The ESMA is an example of a reflection on the status of a regulatory agency in the context of the Meroni doctrine. Article 1 of the regulation establishing the ESMA refers directly to systemic risk. The ESMA may offer additional guidelines and recommendations to systemically important institutions in order to reduce systemic risk. For this reason the ESMA may investigate both the activity of financial institutions and their particular financial products and give recommendations to national authorities. The ESMA in cooperation with the European Systemic Risk Board (ESRB) develops stress tests procedures, which are used to assess the systemic importance of particular market participants. (Frank, 2012)

The ESMA is in possession of instruments influencing financial institutions. There arises a question about the regulatory intensity, the extent of binding effect and legal measures which could be used to challenge the ESMA's decision. The competences of the ESMA, which it took over from the Committee of European Securities Regulators (CESR), were later enhanced especially on Levels 2 and 3 of the Lamfalussy process. The ESMA, like the EBA, develops regulatory and implementing technical standards, which are adopted in the form of delegated Regulations by the Commission at the request of the ESMA. In fact, it is the Commission which has legislative power conferred on it by the Council and the European Parliament. Under Article 290(2)(b) TFEU both these entities may express objection to the standards adopted by the Commission. If that happens, the standards are suspended and do not enter into force.

In addition to technical standards the ESMA issues guidelines and recommendations which formally do not have the force of law but work on the principle of comply or explain. The ESMA acts also as an intermediary in disputes between national authorities. The power of the Commission to initiate a recovery procedure in a member state is not limited by the fact that in the case of a violation of the EU law the ESMA has three instruments at its disposal: non-binding recommendations, negotiations with the participation of the Commission and national regulators and legally binding decisions.

Issuing a binding decision by ESMA is possible only if three cumulative conditions are met: ineffective expiry of the time-limit of negotiations, a need to restore neutral conditions of competition or a need to ensure the orderly functioning of the financial system, and finally, when the regulation directly affects a financial institution, for example, when it comes to standards. Moreover, the decision of the ESMA should be consistent with the opinion of the Commission expressed during negotiations.

When the Council in cooperation with the ESRB determines that there is a situation of a crisis, the ESMA may direct legally binding decisions to national authorities with an aim to 
restore the orderly functioning of the financial system. The ESMA exercises this power under the authorization of the Council. If the measures adopted by a national institution prove insufficient, the ESMA may direct its legally binding decision to a specific financial institution or even suspend its operation. Both financial institutions and national authorities may appeal the ESMA's decision, however, they may not do so with reference to technical standards or guidelines and recommendations. The Board of Appeal, which is a joint body of the European Supervisory Authorities, decides on appeals against the ESMA's decisions. When it finds an appeal justified, the ESMA has to reconsider its decision. The decisions of the Board of Appeal can themselves be appealed to the Court of Justice.

It should be stressed that the ESMA's decisions in a crisis situation or reducing differences in opinion of national authorities are subject to so called budget clause. This means that the member states have a right not to respect the ESMA's resolutions if, in their opinion, they interfere with the budgetary sovereignty. A member state must inform about it the ESMA, the Commission and the Council. Such a statement of a member state suspends the implementation of the decision. In due time the Council determines whether the ESMA's decision will be overruled. If the Council confirms the ESMA's decision, a member state may apply for reconsideration of the decision. The procedure is similar in the case of the ESMA's resolutions settling differences between national institutions.

The Lamfalussy process is a response to the shortcomings of the system based on minimum harmonisation directives, whose implementation was inconsistent and which were often introduced with delays in different member states. These differences, especially gold-plating and inconsistent interpretation of general clauses and vague terms led to regulatory competition between member states with all its negative and positive consequences. However, it did hamper the integration of the common financial market. Therefore, three regulatory levels of the Lamfalussy process were developed and more focus was placed on maximum harmonisation directives and directly applied regulations.

Transformations in the system of the sources of the law gave rise to hybrid forms, which are difficult to classify. Even the ESMA's guidelines and recommendations are to some extent legally binding because they are used by other institutions and national courts (the Grimaldi case) when issuing judgments and they offer possibilities for questioning this kind of ESMA's actions (the Fiskano case). Extensive procedures of consultations with the Commission, the Council and national authorities - the member state must definitely confirm the existence of a situation of a crisis, in which the ESMA is empowered to issue legally binding decisions - cause that the ESMA's non-treaty based position and its executive and technical rather than political powers allay most of the doubts about the compatibility of the ESMA's status with the Treaty (the Meroni case).

Similar doubts concerning the possibility of creating new legal mechanisms outside the Treaty in the context of the European Stability Mechanism were a subject of the Court's consideration in the Pringle case. The European Stability Mechanism (ESM) is based on an agreement between member states. Subject to certain conditions, the ESM may support member states experiencing financial problems. The ESM's instruments can also be used directly to recapitalise banks in a EU member state. In order to do this a decision of a banking supervisor is required and the rules on state aid must be met, including the framework rules for aid to banks.

There are links between the ESM, the European Banking Union and the Single Supervisory Mechanism (SSM). Application of international law (the stability pact) was supposed to be a strategic maneuver aimed at avoiding difficult, complex and unpredictable procedure of amendments to the treaty - especially in the face of the UK's objection - like it was in the case of the Single Resolution Fund (SRF) when Germany was reluctant to mutualisation.

The Supreme Court of Ireland has asked the Court of Justice of the European Union if it is lawful to use simplified revision procedures to introduce rules that provide for the establishment 
of a permanent stability mechanism, and what is more, to create a possibility for the member states of the eurozone to sign an agreement establishing a permanent stability mechanism in compliance with the EU law. The Court envisaged a possibility of the variable geometry of integration by supplementing the EU law regime with provisions of public international law. This judgment is a proof of pragmatism and flexibility of the Court, for which financial stability in the context of European integration is a priority. (Jagiełłowicz, 2013)

Previously the Court refused to examine direct compliance with the law of the amendments affecting the TFEU (O.J. EU C 83/47, 30 March 2010) stating the reason that these amendments were introduced by international agreements between the member states and the Court did not consider itself competent to examine the lawfulness of such agreements. The Pringle case (Case C-370/12), is the first example of court's examination of the constitutionality of amendments to the EU law. ((Schiavo, 2013) The Court's judgment in the Pringle case may be considered one of the most important judgments concerning the EU governance. Not only does it specify the legal framework for intergovernmental groups of member states acting on the matters relevant to the whole European Union, but what is most important, it defines the scope of the lawful differentiation in the situation of particular countries. (Nadolska, 2014)

\section{THE EUROPEAN BANKING UNION AND THE SINGLE SUPERVISORY MECHANISM (SSM)}

The Banking Union means the delegation of sovereignty of member states to the EU institutions. The Single Supervisory Mechanism (SSM) (http://eur-lex.europa.eu/legal-content/ $\mathrm{PL} / \mathrm{TXT} / \mathrm{PDF} /$ ?uri=CELEX:32013R1024\&from=PL) Retrieved March 30, 2016) entails a substantial increase of the role of the ECB. Pursuant to Article 127(6) TFEU after consultation with the European Parliament and the ECB the Council may entrust the ECB with supervision over credit or other financial institutions with the exception of insurance undertakings. However, it is interpreted as merely macroprudential supervision and cannot serve as a basis for the European Banking Union or the Single Supervisory Mechanism (SSM). The range of the ECB's supervisory power can be interpreted following Article 13(2) TFEU, which confers on authorities established pursuant to the Treaty powers that are limited, conditioned and related to issues set out in the Treaty (conferred power).

However, there are still doubts if the term "credit institutions and other financial institutions" includes financial conglomerates, investment firms and shadow banking. It is also not clear to what extent the ECB can take over the function of a national regulator and exercise supervision of the whole financial system by, for example, structural intervention as part of the recovery and resolution mechanism.

There is also a constitutional concern, which is the compatibility of central bank independence in terms of monetary policy with its supervisory power, which, by nature, is not free from political influence, like in the case of the pressure on rescuing a big and important bank. This may lead to an over-lenient monetary policy of the ECB, which will have an adverse affect on price stability. Thus, during the Cyprus EU presidency in 2012 some amendments were introduced to establish institutional guarantees of the independence of the Single Supervisory Board and the Governing Council of the ECB, for example, the chair and vice-chair of the SSB is appointed by Ecofin (Witte, 2014; Cleynenbreugel, 2014, Martinico, 2014; Lo Schiavo, 2014; Kern, 2015; Lehmann, Manger-Nestler, 2014; Berger, 2015; Sherman\&Sterling, 2014)

The ECB's macroprudential supervision covers four areas:

- adaptation of macroprudential norms to particular financial institutions subject to the macroeconomic situation. Introducing, for example, additional procyclical capital requirements or buffers, 
- supervisory analysis of contractual relations between market players (e.g. collaterals, margins, Loan-to-Value or Loan-to-Income ratios for mortgage financing),

- monetary policy instruments, interest rates, capital flow control, money supply,

- prudential requirements for financial institutions of the financial market infrastructure (central counterparties, central depositories, payment, clearing and settlement system).

There arises a question about the legal basis for the application of the whole array of supervision instruments: from ex ante measures of authorisation or monitoring of compliance to ex post measures of crisis management, state aid, guarantee schemes and recovery and resolution planning. Under the Single Supervisory Mechanism (SSM) the Council and the European Parliament have adopted the compromise SSM Regulation, which confers on the ECB additional, strong power exercised by a new body, the Single Supervisory Board (SSB) in particular situations. An example of these new competences is a power to set additional capital requirements or buffers under CRD IV.

All the above instruments are first of all used by regulators, i.e. national supervisory authorities. The ECB may also apply them, however, as additional measures when it is required due to the situation of the country or the whole market. The ECB has more power over banks from countries belonging to the banking union as apart from introducing the buffers, the ECB in cooperation with the SRB may carry out a recovery and resolution plan under the Single Supervisory Mechanism (SSM). The ECB may also apply structural instruments of another type which may force big, systemically relevant banks to separate their commercial and deposit operations. This, in a sense, means to some extent, a return to the old division into investment and commercial banking and a shift away from universal banking.

The question arises, how the governance structure of the SSM should look. In particular, two criteria are being considered: independence and accountability. Independence is understood as an ability to avoid unwanted pressure from other subjects, especially political ones, whereas accountability is a proper relation between such an independent institution and the state, as the institution is obliged to explain and justify its actions, which may be evaluated by other bodies, however, the consequences of this evaluation should not affect institutional independence of the evaluated body as its independence is in the public interest.

In the case of the ECB, independence is an inherent quality of this institution and means independence in performing its tasks and in managing its finances. Article 19 of the SSM Regulation guarantees also independence of the SSB as its new organ. Accountability is reflected in the agreement with the European Parliament and the legal instruments of reporting and hearings. Earlier debates on the independence and accountability of the ECB in its monetary policy may offer some background here.

There arises a problem of the division of tasks between the ECB and national supervisory authorities under the SSM. It is the competence of the ECB to supervise systemically relevant banks in the countries belonging to the banking union and in cross-border cases, when more than one member state is involved. However, ECB also has decisive powers to grant and withdraw authorisations for all banks across the Eurozone, pursuant to procedures (including cooperation with national competent authorities within the SSM) - laid down in the SSM Regulation.

Apart from quantitative criteria of systemic importance such as a bank's assets value exceeding 30 billion or $20 \%$ of GDP of the country of origin and more than 5bn euros, a national regulator may request the ECB to classify an institution as systemically relevant and, thus, to submit it to the ECB's supervision, if the ECB's analysis confirms systemic importance of the institution. Finally, the ECB supervises also banks which are beneficiaries of European or international aid programs.

The SSM is discussed also in the context of granting and taking back a right to provide services by credit institutions. A rule has been adopted that a national regulator serves always as an entry 
point where suitable documents are submitted and where the evaluation if a subject fulfills the criteria required to provide services in the banking sector is performed. If an application is made by a systemically relevant institution, the ECB accepts it or rejects it. The ECB has also the decision making power and takes over the competences of the country of origin when a credit institution wants to establish a branch or to exercise the freedom to provide services within the territory of a country which does not belong to the banking union. Article 17(3) requires the ECB to respect the balance between institutional EU supervision and national supervision.

In this way, the ECB remains the centre of gravity in the SSM and does not infringe on the rights of national regulators, which know their financial markets better, and thereby cooperation with them is beneficial for the execution of the ECB's supervision and ensuring financial stability of the EU. The ECB's ability to exercise its supervisory functions directly is a new standard in the institutional system of the EU. Previously European supervisory authorities did not have such a power and served rather as a forum for exchanging information and consulting legislative proposals. There is little doubt that the ECB's powers are legally binding, which is evidenced by Article 18, which gives the ECB a right to impose administrative penalties.

In order to perform responsibilities conferred on the ECB under Council Regulation (EU) No 1024/2013 the ECB, pursuant to Article 18 of the Regulation, may impose administrative pecuniary penalties if credit institutions, financial holding companies, or mixed financial holding companies, intentionally or negligently, breach a requirement under relevant directly applicable acts of Union law. Thus, the ECB may impose sanctions in a case of a breach of the ECB's decisions and resolutions. In the context of the Single Supervisory Mechanism, when national law is breached, competent national institutions still enjoy the power of imposing sanctions. However, they may impose such sanctions on credit institutions directly supervised by the ECB only when the ECB directs them to start a proceeding. Decisions to impose sanctions are subject to control of the Administrative Board of Review of the European Central Bank and the Court of Justice of the European Union. Cf. Recommendation of the ECB for a Council Regulation concerning an amendment to Council Regulation (EC) No 2532/98 concerning the powers of the European Central Bank to impose sanctions (ECB/2014/19).

However, the ECB can now ensure - to some extent - the uniformity of regulation, as it is the competent authority and can make use of supervisory options and discretions in its own way: The European Central Bank (ECB) published the ECB Regulation on the exercise of options and discretions available in EU law and the ECB Guide on options and discretions available in EU law. These documents lay down how the exercise of options and discretions in banking legislation is to be harmonised in the euro area (https://www.bankingsupervision.europa.eu/ecb/legal/pdf/oj_ jol_2016_078_r_0011_en_txt.pdf Retrieved $30 \mathrm{March}, 2016)$. This is a step in the right direction but still remain some doubts concerning regulatory and supervisory power of the ECB. (Faia, 2015; Kämerer, 2016)

The relations between the ECB and the EBA and between the ECB and the European Systemic Risk Board (ESRB) with reference to macroprudential policy are a subject of a current debate. On the one hand, the SSM Regulation underlines the necessity of tight cooperation between the ECB and the ESRB but, on the other, their supervisory tasks and competences should not overlap. Article 5 of the SSM Regulation confers on the ECB a right to use macroprudential tools. The ECB may increase capital requirements in certain situations, regardless of the actions of national regulators. This instrument of macroprudential supervision puts into question the role of the ESRB and raises doubts about the relations between these two institutions.

There are also doubts and concerns about the SSM distinction between supervision within the eurozone and the banking union and outside of it. However, one may claim that the SSM is a kind of a benchmark for further development of the financial market also for the noneurozone countries and its spill-over effects should have a beneficial impact on them. It needs to be taken into consideration that countries not participating in the SSM will sign memoranda 
of understanding between supervisory agencies. The SSM Regulation affirms that accountability of non-participating countries will be fully respected. Moreover, the Regulation provides for the possibility of signing memoranda of understanding between non-participating countries and the SSM, which, in fact, means joining the SSM, however, without a right to vote. These countries would also be subject to the ECB's supervision, which would make them "second-rate" members.

The SSM encompasses three elements which constitute supervisory authority: power conferred pursuant to the SSM Regulation, power conferred pursuant to internal regulations created under Articles 4, 6 and 9 of SSM Regulation giving the ECB a right to instruct national authorities to apply national law in particular situations and the power to apply the national law by the ECB as the EU supervisory institution.

It is worth underlying that under this system, individual, legally binding decisions directed at particular financial institutions may be issued on the basis of general and abstract regulations. This raises a question about the range and form of legal protection against administrative decisions, which is a standard in democratic countries based on the rule of law. The assumption of the existence of typical legal protection creates a problem of delay or disruption of actions aimed at preserving or strengthening the financial stability of the EU and preventing a financial crisis.

During the discussion on instructive power that the ECB has over all banks and not only those which are systemically relevant some experts invoke Articles 101 and 102 of TFEU about European rules on competition protection, for implementation of which Council Regulation (EC) No 1/2003 was issued. The Regulation establishes interdependence between the Commission and national antitrust regulators. The same matter is subject to both national law and European law and falls within the competences of both the Commission and national institutions and the decision which institution will consider a given case depends on whether the case is of community dimension. However, there are discrepancies as decisions in antitrust cases are of declaratory nature - some anticompetitive activities are illegal even if no such judgment has been passed and banking supervision decisions are constitutive in nature. There are also differences in courts competences: competition protecting cases are in fact civil cases between natural persons and legal entities and administrative courts, which rule on the legality of decisions, may be treated as sui generis supervisory authorities.

Under the SSM, like in the cases concerning the state aid, supervisory decisions may be subject to appeals and are considered by national courts. "Triangular" legal relations are established: the ECB acts vis-à-vis banks but also national regulators. The ECB is obliged to take into consideration all the law, including directives which need to be implemented on a national level and, hence, may not foster cohesion. There might be also conflict situations when the same decision concerning a bank may be taken by a national institution pursuant to a law implementing a directive and also by the ECB, which was conferred with this authority by the SSM Regulation.

Article 4(3) of the SSM Regulation can be interpreted in two ways. The first is transposition of supervisory power. To this end the regulation establishes directly applicable laws. According to the second interpretation Article 4(3) obliges the ECB to follow certain rules in relation with the national supervision. The ECB applies the SSM Regulation looking for a regulation based on the national law and ordering the implementation of supervisory measures. Thus, an obligation to apply a regulation does not change the essence of this regulation. This interpretation is supported by the fact that EU law is constituted by the Treaty, regulations and directives and not national law. One can talk about a spillover effect of both EU law and national law: a spillover of EU law on national law and an influence of national law on EU law, which results in a given EU legal act.

One can expect shaping of new relations between the EBA and the ECB. Naturally, the creation of the banking union strengthened the legal and real position of the ECB. Since 2014 the ECB has been exercising supervisory power over a certain number of big EU banks. Performing this function the ECB must respect the Commission delegated acts created by the EBA, although 
institutional position of the ECB is provided for in the Treaty and the ECB is only one of many regulatory agencies, whose decision making power is limited by the Meroni judgment.

The aim of the ECB under the SSM Regulation is to ensure a level playing field and prepare a supervisory strategy of compliance. This requires tight cooperation of the ECB with banks and national regulators and taking into consideration the differences in risk weights for different categories of assets or so called national options and review options and national discretions.

Banks under direct supervision of the ECB are subject to closer scrutiny of the Supervisory Review and Evaluation Process (SREP) and the Asset Quality Review (AQR). However, the review is usually carried out based on the data from national supervisors gathered under Internal Capital Adequacy Assessment Process (ICAAP) and Internal Liquidity Adequacy Assessment Process (ILAAP), as well as quarterly collected data on credit and market risk, liquidity, profitability, investments, etc. The ECB attaches special importance to capital planning of banks which failed Asset Quality Review and stress tests.

The Single Supervisory Mechanism (SSM) is based on three legal pillars:

- Article 127(2) of TFEU, which confers regulatory power on the ECB,

- the SSM Regulation (http://eur-lex.europa.eu/legal-content/PL/TXT/PDF/?uri=CELEX:320 13R1024\&from=PL Retrieved March 30, 2016) which outlines regulatory tasks for the ECB, - the SSM Framework Regulation (http://eur-lex.europa.eu/legal-content/PL/TXT/PDF/?uri $=$ CELEX:32014R0468\&from $=$ EN Retrieved March 30, 2016 ) regulating the cooperation between the ECB and national supervisory authorities.

This last regulation underlines the fact that partners must act in good faith and exchange information. The answer to the question which entity should supervise a given institution on the basis of the criteria specified in Article 6(4) of the SSM Regulation depends on the systemic relevance of this institution defined according to Part IV of the SSM Framework Regulation.

The SSM Framework Regulation specifies some procedures, for example, Article 22 stipulates that the ECB may not make use of procedures which are not set out in national law. This causes concern about how the ECB should behave towards national banks. There is also a question about interpretation and the practice of implementing EU law in this context: are there areas where EU law will not be applied and areas where national law is not based on EU law. How should the ECB act in such situations?

In such situations the ECB and national regulators would have to collaborate closely and national regulations would be applied by a national institution. National regulations are in most cases based on European law, for example, policy of remuneration for bank employees under CRD IV. In the light of both regulations concerning the SSM it is the ECB which decides whether financial institutions being subject to Capital Requirements Regulation, which means not only credit institutions, are systematically relevant.

It is worth noticing that the scope of Article 6(4) of the SSM Regulation is unclear. It provides for a threshold of EUR 30 billion, over which an institution cannot be classified as not systemically relevant and in such a case it is clear who the regulator is. However, the SSM Regulation provides for many exceptions to the main criterion, which may be a premise for the decision to bring the institution under national supervision.

Detailed criteria for such exceptions have not been defined yet. There have been cases when institutions applied for such an exemption but due to the lack of criteria the applications could not be considered and were rejected. The Administrative Board of Review, a new organ created pursuant to Article 24 of the SSM Regulation, is entitled to present opinions about the decisions taken by the ECB.

However, taking into consideration that, pursuant to Article 256 TFEU, the European General Court has jurisdiction over the ECB's decisions, the lack of procedures impedes exercising of this jurisdiction. It is true that resolving disputes concerning the regulation of the financial market 
in court is not common as financial institutions are unwilling to undermine good relations with a regulator. However, fees imposed pursuant to Article 18 of the SSM Regulation are much higher than those imposed by a national regulator, therefore, one can expect an increase in the number of cases settled in court. In conclusion, the ECB in its new role of a regulator of regulators will face some new challenges like, for example, making use of experience of national supervisors on the Supervisory Board. (Hanten, Heljula, 2015)

As it is unlikely that the responsibility for macroprudential policy will rest with a single institution, it is important to assign key functions in such a way that will allow avoiding gaps and inconsistencies. A system of regulations should take account of such aspects as: requirements of interinstitutional coordination and exchange of information, autonomy, management, accountability and transparency.

\section{THE EUROPEAN BANKING UNION AND THE SINGLE RESOLUTION MECHANISM (SRM)}

Under the Single Supervisory Mechanism stress tests of a broader scope were run, preceded by Asset Quality Review covering a larger number of subjects, i.e. banks. These tests are not new but serve here a different purpose. Their purpose is not bank risk management but they are a macroeconomic tool which measures the financial system's resistance to crises. Stress tests include scenario and sensitivity analysis and the focus is placed on combined occurrence of unfavourable factors. The fact that stress tests are not intended only for communication between two subjects: the supervisor and the supervised institution, but they are also published, may increase discipline and transparency of the market. Whether such an impact does exist is a subject of empirical studies. For example, there are studies on the influence of stress tests on share prices. (Horsch, Kleinow, 2015)

In 2014 twenty six member states signed the intergovernmental agreement on the transfer and mutualisation of contributions to the Single Resolution Fund (SRF). An international agreement is an essential component of the European Banking Union and thus of the Single Supervisory Mechanism (SRM), whose aim is the recovery and resolution of endangered banks of the eurozone. The SRF is part of this mechanism.

It is interesting to notice that the SRF was established pursuant to international law. From a legal point of view choosing a way of an international agreement was unjustified. The reason given for using international law was the argument that the EU cannot unilaterally impose financial burdens on the member states. However, international law gives rise to uncertainty with reference to the European policy in this matter. Nonetheless, the European Parliament recommended a regulation which would prohibit national actions going beyond the single European mechanism. The banking union is based on three pillars: the SSM, the SRM and a common deposit guarantee scheme. Applying international law, outside European law, for the SRF may disturb the institutional balance of the banking union.

The problem of recovery and resolution of credit institutions raises concerns about the implementation of the BRR Directive. The objective of the Directive is to establish a framework for the recovery and resolution of banks. Due to the size, complexity and mutual interconnection, resolution of endangered banks is not easy as, on the one hand, it may cause a chain reaction and a domino effect and, on the other, it poses a danger to the real economy.

To minimize these problems banks all over the world were bailed out. The owners and creditors were protected against enormous losses, which were distributed over all taxpayers. At that time a maxim about "privatizing profits and socializing losses" was coined. This implicit government guarantee increased moral hazard and pressure on excessive exposure to a risk higher than it was economically justified. In Poland the BRR Directive will be implemented through an amendment 
to the Bank Guarantee Fund (BGF) Act of 10 June 2016 (Official Journal of 2016, item 996). The BGF is supposed to receive supplementary powers in recovery and resolution of banks. This appears to be an appropriate solution because so far, apart from guaranteeing deposits, the BGF's has been also empowered to offer support. The recovery and resolution regulation in Germany is an interesting case from the point of view of the evolution of such regulation.

In Germany already in 2010 a law on banks restructuring (Kreditinstitute-Restrukturierungsgesetz) was passed and then in 2013 - a law that imposes restrictions on combinging commercial and investment banking (Trennbankengesetz - Gesetz zur Abschirmung von Risiken zur Planung der Sanierung und Abwicklung von Kreditinstituten und Finanzgruppen). Thus, Germans are pioneers of regulations which were later found apropriate in the whole EU. Later Germany passed also a law (Sanierungs- und Abwicklungsgesetz - SAG), which incorporates all essential BRR Directives in national law. The previous regulations of banking law (Kreditwesengesetz - KWG) concerning recovery and resolution of banks were annulled.

In the eurozone the BRR Directive was systemically supplemented by the SRM Regulation. (http://eur-lex.europa.eu/legal-content/PL/TXT/PDF/?uri=CELEX:32014R0806\&from=PL Retrieved March 30, 2016) The Regulation invoking the BRR Directive establishes uniform conditions of recovery and resolution of banks in the eurozone. Recovery and financial decisions will be made by a new body, the Single Resolution Board (SRB), in cooperation with the Single Resolution Fund (SRF). The BRR, the SRM Regulation Directive and the Deposit Guarantee Scheme (DGS) constitute the foundations for the banking union. (Engelbach, Friedrich, 2015; Fabrini, 2014; Binder, 2015)

The key element of the BRR Directive is recovery plans, which must be prepared by all banks and not only those in bad financial situation. These plans have to be regularly updated. They are supposed to be an instrument preparing banks in advance for difficult situations. Pursuant to the SRM Regulation similar business reorganisation plans are prepared by organs responsible for restructuring of credit institutions. The objective is to establish a new procedure which would take account of multilateral and complex relations in the banking sector and to create a systemic approach that would take into consideration these relations. This objective is not fulfilled under the current bankruptcy proceedings. Thus, there are two interrelated instruments: recovery plans and business reorganisation plans, which corresponds with the concept of Key Attributes of Effective Resolution Regimes for Financial Institutions developed by the Financial Stability Board (FSB) in 2011. The requirement to prepare recovery plans by all banks is a new idea, until recently only banks at risk of bankruptcy had to prepare such plans.

Business reorganisation plans should foresee probable scenarios of the development of a crisis situation and answer, for example, the question whether a bank should be restructured or it should file for bankruptcy. However, this does not have to mean the termination of the bank's operations. It may continue its operations after a sale of the whole bank or a bail-in, when the owners or bondholders are obliged to recapitalise the bank. There is a possibility of transferring liabilities to so called a bridge institution, a private or state one.

Reorganisation plans are created with some objectives in mind, such as: maintaining the continuity of a bank's operations, protection of clients' resources, preserving trust in the financial market and avoiding the necessity of state aid. Pursuant to the BRR Directive a reorganisation plan should be implemented if an institution is at risk of bankruptcy. The assets and liabilities of the institution are evaluated by experts and auditors appointed by court. However, time pressure may cause that these proceedings can infringe on the owners' rights, which are limited under this procedure. The decision to implement a business reorganisation plan cannot be appealed, however, it is possible to file a complaint with superior Administrative Court, which will not stop the proceeding. Nonetheless, the court may only rule whether the decision was legitimate and not whether it was justified. 
Business reorganisation plans are prepared individually for each institution, including also holding companies. However, there are different strategies concerning big groups of companies. For example, there is Single Point of Entry (SPOE) option, where the plan concentrates on the holding or parent company and Multiple Point of Entry (MPOE) model, where endangered subsidiaries are examined. The SPOE strategy often involves transferring bad debts to a bridge institution and obliging the owners to recapitalise the bank. As a result, the business operation of the bank can be continued to the benefit of its clients, the bank's reputation and confidence in the bank. Different jurisdictions of the bank's subsidiaries, causing logistical, legal, organizational and coordination difficulties are a frequent problem of MPOE.

The problem of banks too big to fail is extremely expensive for taxpayers, depletes state finances, distorts the competition and increases moral hazard. That is why - in the context of the BRR Directive and the SRM Regulation - the EU created a concept of a bail-in, which means transferring the cost of restructuring or bankruptcy of a bank to the owners and creditors and not to all taxpayers. In the USA, pursuant to Dodd-Frank Act, a new body, the Orderly Liquidation Authority, was established. The authorities competent to introduce recovery and resolution procedures have broad powers and, to some extent, may influence the market conditions, change the order or the date of payments and even cancel liabilities or prevent a closure of a contract in the derivatives market. The concept of bail-out causes many problems, especially problems connected with the future of derivative contracts. Therefore, a new ISDA glossary contains such terms as: financial reference entity with standard reference obligations and governmental intervention as market events under Recovery and Resolution procedure. Standard procedures provided for by ISDA may be supplemented by arrangements between parties to the contract. These changes were inspired by, among others, the SNS Bank and Bankia cases. It is about the guarantee that the seller of an instrument will get the payment, so called deliverable obligation (Benton, Ajitsaria, 2014; Dwyer, Tredgett, 2014).

The conditions of constructive certainty have to be guaranteed, e.g. a bank's access to liquidity, which will ensure gone-concern loss absorbing capacity (GLAC). The objective of GLAC is to create for a bank opportunities to increase CET1 capital to the required minimum. For global systemically important institutions resolution plans are created by authorities competent to introduce recovery and resolution procedures in cooperation with the Crisis Management Group $(\mathrm{CMG})$, which comprises central banks, financial market supervisory authorities and recovery and resolution authorities of each country where parts of a given G-SIFI holding company operate (Huertas, 2014).

Total Loss-Absorbing Capacity (TLAC) framework creates additional capital requirements for global systemically important financial institutions. It is due to the fact that during the crisis big banks were considered "too big to fail" and governments felt obliged to rescue banks at the taxpayers' expense. The importance of imposing additional requirements and thus reducing the moral hazard of G-SIFIs has been underlined by the FSB in its numerous documents (FSB, 2010; FSB, 2014). This also inspired the European Legislator to issue the BRR Directive.

Under the banking union, the SSM and the SRM abandoning the traditional institution of bankruptcy and taking account of multilateral relations in the financial system, which is provided for in the BRR Directive and the SRM Regulation, aims at ensuring financial stability and preventing a contagion effect. However, this is criticized from the point of view of politics and competition law. There are opinions that rescuing failing banks in a special, institutional way will distort competition and cause a loss of welfare and well-being and long-term state support strain on the budget when the SRF resources prove inadequate. Similar criticism refers also to guarantees for depositors and investors.

It should be stressed that the Single Resolution Mechanism (SRM) in the eurozone and a new system of recovery and resolution of credit institutions based on the BRR Directive in the whole EU do not render the system of state support for banks unlawful (Kok, 2015). State support for 
banks may be an important tool when bail-in and resources from the Single Resolution Mechanism (SRM) are not sufficient. Under this system the Commission examines the viability of a bank, or effectiveness of support, burden sharing and competition - in order to ensure equal conditions of competition restrictions may be imposed on the bank. To some extent, the Commission takes account of the nature of an aid to banks, which has to guarantee financial stability and prevent systemic risk. In order to ensure this the Commission may use both structural and behavioral measures. Since the beginning of the crisis the Commission has produced a number of guidelines.

The question of interdependence of Deposit Guarantee Schemes Directive (DGSD) and the BRR Directive arises. It is important to notice the change of the role of the guarantors of deposits in crisis management. They contribute to the financing of restructuring plans, so called paybox function. The role of a guarantor of deposits under the enhanced model of crisis management is essential. Good resolution procedures ensure continuous access to guaranteed deposits, which causes that there is no need to pay out the deposited funds. When eligible deposits at an institution under resolution are transferred to another entity through P\&A tool or the bridge institution tool, the depositors have no claim under Article 109(4) of the BRR Directive 2014/49/EU against the deposit guarantee scheme. In fact, resolution instruments are a substitute for classic disbursement of guaranteed funds. They should enable resolution of the whole or part of a financial institution in an orderly manner and timely disbursement of guaranteed deposits or their transfer to another entity. Transferring guaranteed deposits through P\&A tool is one of the options.

\section{THE REGULATORY BACKGROUND OF SSM, SRM IN THE EUROPEAN BANKING UNION}

Not without significance for the functioning of the European system of financial supervision is the partial transfer of supervisory powers to the European level (SSM, SRM). In this context, the fact that national regulators were given wide discretionary powers (due to a number of so-called national options) may be a source of practical problems (i.e. divergence between national supervisory practices). However, EU Member States must keep some options and discretions because of specific economic issues in different countries (European Parliament, 2016; EBI Workshop, 2016; Kunschke, Huertas, 2016). Therefore, there is a contradiction between the need to ensure a high level of regulatory uniformity and the need to take into account the specificity of local financial markets.

In addition, there are still many doubts or inconsistencies e.g. concerning legal protection in SSM and SRM. (Kämerer, 2016). Therefore, an integrated approach to the financial market law is needed. This can be seen in regulatory packages such as CRD IV / CRR, MiFID 2 / MiFIR, and other acts such as EMIR, Solvency 2, PSD, where regulations include also activities of near-banks including Fin-Tech institutions (E. Faia, A. Hackenthal, M. Haliassos, K. Langenbucher, 2016).

Regulations combining the purposes of micro- and macro-prudential policy which are aimed at counteracting pro-cyclicality and minimizing the impact of other factors of systemic risk should generally be appreciated.

Capital adequacy standards established under Basel III with a view to reducing the risk of crises, despite the generally positive assessment also raise some criticism. Similar discussions taking place around the new, complicated tools used to cover the costs of the crisis by creditors and bank owners (bail-in instead of bail-out), the concept of MREL (minimum requirements for own funds and by eligible liabilities) the concept of TLAC (total loss absorbing capacity). Concerns are expressed that the requirements are excessive as they will induce banks to take excessive risks or forcing too higher prices of financial services to consumers. In addition, high and restrictive capital requirements can result in shifting the part of the banks to the realm of 
banking shadow (shadow banking), which is not fully subject to the regulatory requirements (Long, Bannister, 2015).

Many problems arise as a result of the lack of global harmonization of trading derivatives and the lack of comparability of clearing houses (central counterparties - CCP). In the EU CCP situated outside the EU require approval by a decision of ESMA, on the basis of the consent of the Commission. In Asia, regional regulations are initiated that follow the pattern of the European AIFMD and EMIR. Moreover, there arises the question, to what extent should near-banks, including FinTech, be granted the access to the financial market infrastructure (clearing and settlement services), without prejudice to financial security and stability (Wickersham, 2015).

We have to deal with the regulation on transparency of securities financing transactions and of reuse, which will help to monitor also near-banks (the requirement of reporting of transactions to registered trade repositories). It expanded the disclosure requirements applicable to the management of investment funds, and tightened the requirements for reuse of collateral. Important is also the Regulation on the indexes used in the financial market, which expanded the list of indexes (e.g. not only LIBOR, but the DAX or indexes of commodity markets), explains the key issues related to the establishment and use of indexes to reflect market realities and not to cause conflicts of interest. (Brändli, Guggenheim, Jüttner, 2015)

Also the new regulatory package on the European Capital Markets Union should be mentioned. The aim of the European Commission is a differentiation of sources of financing of enterprises, especially small and medium-sized. The EU provides a wide and accessible market for debt securities (simple, transparent and standardized securitizations - STS), which also requires changes to CRR Regulation. At stake are: a new approach to cover capital for investment in infrastructure projects and the principles of financing with the risk capital. In the context of extending the sources of financing for small and medium-sized businesses it should be emphasized that crowdinvesting platforms are already regulated in many countries. (Pötzsch, 2016; Ovenden, Stubbs, 2015)

The study has verified the hypotheses concerning the importance of regulations - in the compliance context - as a strategic tool and an element of the new strategic thinking. (Poniatowska - Jaksch Ed. 2016). However, the EU must take further action within the financial market institutions in order to fully implement the European Banking Union. The new macro-prudential supervision regime has a bearing on the existing institutions (e.g. the development of new tasks both for the ECB and national supervisory authorities). This new regime also supplemented, in the legal sense, a broad understanding of systemic risk, pointing to specific areas where the macro-prudential supervision should particularly pursue its goals, i.e. capital buffers and countercyclical actions.

Both the ECB and the EU authorities recognised the inadequacy of existing regulations, and even more - the lack of appropriate institutional solutions, which was a prerequisite for the establishment of the so-called de Larosière Group. Hence, a series of solutions have been developed so as to, firstly, stop the functioning of the adverse phenomena in the financial markets and, secondly, to create defense mechanisms that would protect the economy against similar phenomena in the future.

With respect to the economic analysis of the banking union regulation it should be stressed, however, that a full quantitative impact assessment is not possible due to the information deficiencies, gradual implementation of the regulations, including executive acts, difficulties in separating the impact of individual legal acts on the market, complementarity and substitutability of the impact of the given regulations, the interdependencies (synergies or conflicts) between them, ever new possibilities of circumventing the law through financial innovations (law arbitration) or regulatory competition that occurs between national jurisdictions. In this context it is worth mentioning that a new innovative concept is used to study the so-called principle 
of proportionality has been elaborated recently. It consists of 3 components (proportionality in the strict sense, the appropriateness and necessity). It is an example of an analytical approach in relation to the regulatory impact assessment which places value not only on quantitative analysis, but also - to a large extent - on qualitative considerations (Kasiewicz, Kurkliński, Szpringer 2014).

\section{CONCLUSIONS}

There is a risk of excessive centralization of the ECB's competences, which may lead, on the one hand, to a decision paralysis, and, on the other, to the ECB's excessive power over the market and financial institutions and to the appearance of new challenges of the ECB supervision. According to the judgement of the Court of Justice of the EU, the scope of regulatory powers of the EBA and the ESMA is compliant with the Treaty (Meroni case).

The centralization of supervision in the ECB is seen as an institutional addition to the banking union and the common currency, the euro. The banking union means the delegation of sovereignty of member states to the EU institutions. The SSM entails a substantial increase of the role of the ECB in context of the role of ESRB or EBA. There are two options to strengthen the SSM: the expansion of the supervisory role of the ECB or the enhancement of the functions of the EBA.

It is unlikely that the responsibility for macroprudential policy will rest with a single institution, it is important to assign key functions in such a way that will allow avoiding gaps and inconsistencies. A system of regulations should take account of such aspects as: requirements of interinstitutional coordination and exchange of information, autonomy, management, accountability and transparency.

The ECB's ability to exercise its supervisory functions directly is a new standard in the institutional system of the EU. The ECB may increase capital requirements in certain situations, regardless of the actions of national regulators. This instrument of macro-prudential supervision puts into question the role of the ESRB and raises doubts about the relations between these two institutions.

In addition, there arises a problem of the division of tasks between the ECB and national supervisory authorities under the SSM. It is the competence of the ECB to supervise systemically relevant banks in the countries belonging to the banking union and in cross-border cases, when more than one member state is involved. However, ECB is also solely competent to grant and withdraw authorizations and to accept, or reject, shareholders in banks as fit and proper across the Eurozone, i.e. for all banks.

The SSM and the SRM abandoning the traditional institution of bankruptcy and taking account of multilateral relations in the financial system, which is provided for in the BRR Directive and the SRM Regulation, aims at ensuring financial stability and preventing a contagion effect. However, this is criticized from the point of view of politics and competition law.

The SSM is discussed also in the context of granting and taking back a right to provide services by credit institutions. A rule has been adopted that a national regulator serves always as an entry point where suitable documents are submitted and where the evaluation if a subject fulfills the criteria required to provide services in the banking sector is performed.

The relations between the ECB and the EBA and between the ECB and the ESRB with reference to macroprudential policy are a subject of a current debate. On the one hand, the SSM Regulation underlines the necessity of tight cooperation between the ECB and the ESRB but, on the other, their supervisory tasks and competences should not overlap. The ECB and national regulators would have to collaborate closely. 


\section{Bibliography}

Armstrong K. The legal limits to "agencification" in the EU? Case C 270/12 UK v. Parliament and Council http:// europeanlawblog.eu/?p=2176 Retrieved March 30, 2016.

Shearman\&Sterling (2014) Banking Supervision within the Eurozone. The Single Supervisory Mechanism, http:// www.shearman.com/ /media/Files/NewsInsights/Publications/2014/11/Banking-Supervision-Within-theEurozone-The-Single-Supervisory-Mechanism-FIAFR-111714.pdf Retrieved March 30, 2016.

Bauer D. A., Werner K. (2015) TLAC-Neue Herausforderungen für die Kapitalstruktur? "Zeitschrift für Wirtschaftsund Bankrecht" No 24.

Benton D., Ajitsaria S. (2014) The new 2014 ISDA Credit Derivatives Definitions "Butterworths Journal of International Banking and Financial Law" No 7-8.

Berger H. (2015) Der einheitliche Aufsichtsmechanismus (SSM) - Bankenaufsicht im europäischem Verbund "Zeitschrift für Wirtschafts- und Bankrecht" No 11.

Binder J. H. (2015) Gleichung mit (zu) vielen Unbekannten: Nachhaltige Bankenstrukturen durch Sanierungs- und Abwicklungsplanung „Zeitschrift für Bankrecht und Bankwirschaft“ No 3.

Brändli B. Guggenheim B., Jüttner M. (2015) Financial Benchmarks: Bedeutung, Problematik und regulatorische Ansätze „Schweizerische Zeitschrift für Wirtschafts- und Finanzmarktrecht” $\mathrm{nr} 2$.

Christensen T (2005) Agencification and Regulatory Reforms Stanford University, 2005, http://soc.kuleuven.be/io/ cost/pub/paper/AgencificationRegulatioryReforms_Final21021.pdf Retrieved March 30, 2016.

Cleynenbreugel P. (2014) Meroni Circumvented? Art.114 TFEU and Regulatory Agencies "Maastricht Journal of European and Comparative Law" Vol. 21, No 4.

Deloite (2015) The Single Supervisory Mechanism. Getting to Grips with the New Regime http://www2.deloitte.com/ content/dam/Deloitte/uk/Documents/financial-services/deloitte-uk-single-supervisory.pdf Retrieved March 30, 2016.

Dwyer, E. Tredgett R. (2014) OTC derivatives: Client Clearing Agreements: framing the main negotiation "Butterworths Journal of International Banking and Financial Law" No 7-8/2014.

EBI Workshop: Challenges for banks in a changing regulatory environment, Frankfurt 27-28 January 2016 https://www.ebi-edu.eu/files/Presentation\%20Slide\%20Packs\%20Conference\%2027-28-01/20160127\%20 Presentation\%20Prof\%20Bart\%20Joosen.pdf.

Engelbach S., Friedrich T. (2015) Die Umsetzung der BRRD in Deutschland „Zeitschrift für Wirtschafts- und Bankrecht" No 14.

Fabrini F. (2014) On Banks, Courts and International Law. The Intergovernmental Agreement on the Single Resolution Fund in Context „Maastricht Journal Of European and Comparative Law" Vol. 21, No 3.

Faia E.,, Schnabel I. (2015), The Road from Micro-Prudential to Macro-Prudential Regulation oraz T. H. Tröger A Political Economy Perspective on Common Supervision in the Eurozone, in: E. Faia, A. Hackenthal, M. Haliassos, K. Langenbucher (eds.), Financial Regulation. A. Transatlantic Perspective, Cambridge University Press, Cambridge 2015.

Fedorowicz M. (2014) W sprawie przyszlej organizacji nadzoru makroostrożnościowego w Polsce „Bezpieczny Bank" Nr 4.

Fedorowicz M. (2011) Regulacja nadzoru nad rynkiem finansowym w UE - integracja czy dezintegracja prawnych instrumentów antykryzysowych „Ekonomia i Prawo” Tom VII.

Ferran E. (2015) The Existential Search of the European Banking Authority University of "Cambridge Faculty of Law Working Papers" No 40.

http://papers.ssrn.com/sol3/papers.cfm?abstract_id=2634904 Retrieved March 30, 2016.

Frank A. (2012) Die Rechtswirkungen der Leitlinien und Empfehlungen der Europäischen Wertpapier- und Marktaufsichtsbehörde Baden-Baden, Nomos.

Görisch Ch. (2012) Die Agenturen der Europäischen Union "Jura" No 1, www.degruyter.com Retrieved March 30, 2016.

Griller S. The European institutional setup on financial regulation - Meroni revisited http://www.eba.europa.eu/ documents/10180/498024/Presentation+-+Stefan+Griller.pdf Retrieved March 30, 2016.

Gurlit E., Instrumente makroprudenzieller Bankenaufsicht - unter besonderer Berücksichtigung zusätzlicher Kapitalanforderungen Teil I und II, „Zeitschrift für Wirtschafts- und Bankrecht“ Nr 26/2015 oraz Nr 27/2015.

Hanten M., Heljula K. (2015) The ECB as the new regulator: a lawyer's perspective "Butterworths Journal of International Banking and Financial Law", April, 2015.

Horsch A., Kleinow J. (2015) Der Bankenstresstest 2014 im Vorfeld des Single Supervisory Mechanism: Theorie und Empirie zu einem Lackmustest der neuen europäischen Bankenregulierung „Zeitschrift für Bankrecht und Bankwirtschaft", No 1. 
Huertas T. F. (2014) From bail-out to bail-in: are banks becoming safe to fail? "Butterworths Journal of International Banking and Financial Law" No 9.

Jacobsson B., Sundström G. (2007) Governing State Agencies. Transformations in the Swedish Administrative Model Pisa, ECPR, http://www.score.su.se/polopoly_fs/1.26595.1320939800!/20075.pdf Retrieved March 30, 2016.

Jagiełłowicz Ł. (2013) W stronę Europy zmiennej geometrii? Analiza orzeczenia Trybunatu Sprawiedliwości UE w sprawie Europejskiego Mechanizmu Stabilności, Centrum Europejskie Natolin, „Analiza Natolińska” No 3, http://www.natolin.edu.pl/pdf/analizy/Natolin_Analiza_3_2013.pdf Retrieved March 30, 2016.

Jurkowska-Zeidler A. (2008) Bezpieczeństwo rynku finansowego w świetle prawa Unii Europejskiej WoltersKluwer, Warszawa.

Kasiewicz S., Kurkliński L. „Szpringer W. (2014) Zasada proporcjonalności. Przełom w ocenie regulacji, ALTERUM Centre for Research and Analysis of Financial System, Warsaw.

Kämerer J. A. (2016) Rechtsschutz in der Bankenunion „Zeitschrift für Wirtschafts- und Bankrecht” Nr 1.

Kern A. (2015) European Banking Union: a Legal and Institutional Analysis of the Single Supervisory Mechanism and the Single Resolution Mechanism "European Law Review" No 4.

Kok J. (2015) Competition Policy in the Framework and Application of State Aid in the Banking Sector "European State Aid Law Quarterly" Vol. 14, No 2.

Koleśnik J. (2013) Europejska unia bankowa - nowy wymiar ryzyka systemowego „Problemy Zarządzania” No 2.

Kunschke D., Huertas M. (2016) Regulation 2016/445 of the European Central Bank on the Exercise of Options and Discretions Available in Union Law (the NODE Regulation): A Milestone towards a Single Rulebook for all Banks in the EU? "Journal of International Banking Law and Regulation" Issue 8.

Lehmann M., Manger-Nestler C . (2014) Einheitlicher Europäischer Aufsichtsmechanismus: Bankenaufsicht durch die $E C B$ "Zeitschrift für Bankrecht und Bankwirtschaft", No 1.

Long, A. Bannister A., (2015) The shadow of MREL and TLAC „International Financial Law Review” nr 4.

Martinico G. (2014) Assymetry and Complex Adaptive (Legal) Systems: the Case of the European Union "Maastricht Journal Of European and Comparative Law" Vol. 21, No 2.

Moynihand D. P. (2006) Ambiguity in Policy Lessons: The Agencification Experience Public Administration Vol. 84, No 4 http://www.lafollette.wisc.edu/facultystaff/moynihan/PA06Ambiguity.pdf Retrieved March 30, 2016.

Nadolska A. (2014) O charakterze prawnym decyzji Europejskich Urzędów Nadzoru - rozważania w kontekście sprawy C-370/12 Pringle „Zeszyty Prawnicze BAS no 1(41), http://orka.sejm.gov.pl/wydbas.nsf/0/D342BC2D CC14D897C1257D07003A3BD3/\$File/Strony\%20od\%20Zeszyty\%20Prawnicze\%201\%202014_Nadolska.pdf Retrieved March 30, 2016.

Ovenden S., Stubbs D., Practice What You Preach „International Financial Law Review” nr 11.

Poniatowska-Jaksch M. (Ed.) (2016) Tools in Business Management. Towards a New Strategic Thinking SGH Publishing House, Warsaw.

Pötzsch T. (2016) Aktuelle Schwerpunkte der Finanzmarktregulierung - national, europäisch, international „Zeitschrift für Wirtschafts- und Bankrecht” Nr 1.

Pruski J. (2014) Ewolucja światowego systemu ochrony depozytów oraz systemu recovery i resolution, IX Kongres Ryzyka Bankowego, Warszawa, http://www.bfg.pl/sites/default/files/dokumenty/prezentacja_prezesa_zarzadu_ bfg_na_ix_kongresie_ryzyka_bankowego.pdf Retrieved March 30, 2016.

Repasi R. (2012) A study on the legal feasibility of perspectives of reforms towards a genuine European economic and monetary union, European Parliament, www.sven-giegold.de Retrieved March 30, 2016.

Lo Schiavo G. The European Supervisory Authorities. A True Evolutionary Step along the Process of European Financial Integration http://www.tf.vu.lt/dokumentai/Admin/Doktorant\%C5\%B3_konferencija/Schiavo.pdf Retrieved March 30, 2016.

Lo Schiavo G. (2013) The Judicial 'Bail Out' of the European Stability Mechanism: Comment on the Pringle Case College of Europe, "Research Papers in Law” No 9 https://www.coleurope.eu/system/files_force/research-paper/ researchpaper_9_2013_loschiavo.pdf Retrieved March 30, 2016.

Lo Schiavo G. (2014) From National Banking Supervision to a Centralised Model of Prudential Supervision in Europe, Maastricht Journal of European Comparative Law, Vol. 21, No 1/2014.

Schoenmaker D., Allocating macroprudential powers, ESRB, Reports of Advisory Scientific Committee Nr 5 , November 2014, https://www.esrb.europa.eu/pub/pdf/asc/Reports_ASC_5_1411.pdf?9edec4e98fd4a72eb2cbcb 88a646a1c6\#page=1\&zoom=auto,-12,842.

Stanisławiszyn P. (2014) Nadzór makroostrożnościowy w Unii Europejskiej. Jak bardzo potrzebny? Jak bardzo skuteczny?, [w:] Nowe koncepcje nadzoru i regulacji rynku finansowego pod red. W. Rogowskiego, Oficyna Wydawnicza Instytutu Allerhanda, Warszawa-Kraków.

Szczepańska O. (2012) Nadzór makroostrożnościowy „MF Bank” Nr 10.

Szpringer W. (2015) Prawo i ekonomia stabilności finansowej Oficyna Wydawnicza SGH, Warszawa.

Szpringer Z. (2013) Unia Bankowa Seria: Infos, No 3, Warszawa, Kancelaria Sejmu RP.

Thomas S. (2014) Die kartellrechtliche Bewertung des sog. Kapitalmarktrechtlichen “cornering” „Wirtschaft und Wettbewerb", No 2. 
Tröger T., Regulatory Influence of Market Conditions in the Banking Union, ,SAFE Newsletter” Nr 3/2015, www. safe-frankfurt.de/news-media/newsletter.html

Węc J. (2014) Proces konstytuowania Unii Bankowej. Geneza, podstawy prawne, cele i zasady działania „Rocznik Integracji Europejskiej”, No 8, http://pressto.amu.edu.pl/index.php/rie/article/view/485, Retrieved March 30, 2016.

Wickersham C. (2015) New World Disorder „International Financial Law Review” nr 11.

Witte A. (2014) The Application of National Banking Supervision Law by the ECB: Three Parallel Models of Executing EU Law "Maastricht Journal of European and Comparative Law" Vol. 21, No 4.

Zaleska M. red., (2013) Unia bankowa, Difin, Warszawa.

Zetsche D. (2014) Beihilfe durch Staatliche Kreditgewährung an die Entschädigungseinrichtung der Wertpapierhandelsunternehmen: Der Fall Phoenix „Wirtschaft und Wettbewerb“ No 10.

Zimmer D., Weck T., Schepp N. P. (2014) Wiederherstelung des Wettbewerbs als Ordnungsprinzip auf den Finanzmärkten: Ist die Bankenunion ein taugliches Mittel hierzu? „Zeitschrift für Wettbewerbsrecht“"No 3. 